\title{
ARTICLE
}

\section{Intensive culture system of Litopenaeus vannamei in commercial ponds with zero water exchange and addition of molasses and probiotics}

\author{
Sistema de cultivo intensivo de Litopenaeus vannamei en viveros comerciales \\ sin recambio de agua con la adición de melaza y probiótico

\section{Enox de Paiva Maia ${ }^{1}$, George Alves Modesto ${ }^{1}$, Luis Otavio Brito², Alfredo Olivera Galvez ${ }^{2}$ and Tereza Cristina Vasconcelos Gesteira ${ }^{3}$}

\author{
${ }^{1}$ Aquarium Aquicultura, Varzea da Ema s/n, Zona Rural, Mossoró, RN, Caixa Postal: 05, Brazil. enoxmaia @ hotmail.com \\ ${ }^{2}$ Departamento de Pesca e Aquicultura, Universidade Federal Rural de Pernambuco, Rua Dom Manoel de Medeiros, Dois Irmão, 52171- \\ 900, Recife, PE, Brazil \\ ${ }^{3}$ Centro de Diagnóstico de Enfermidades de Organismos Aquáticos, Instituto de Ciências do Mar, Universidade Federal do Ceará, \\ Avenida da Universidade, 2853, Benfica, Fortaleza, CEP: 60020-181, Brazil
}

\begin{abstract}
Resumen.- Se realizó un estudio de 16 semanas para evaluar el sistema de cultivo de Litopenaeus vannamei en viveros comerciales sin recambio de agua con la adición de melaza y probiótico. Se utilizaron 2 estrategias de manejo: ML (melaza) y PML (probiótico comercial y melaza) con 4 repeticiones en cada caso. Camarones $L$. vannamei $(2,09 \pm 0,3 \mathrm{~g})$ fueron sembrados en viveros $(2,6$ ha sin liner) a una densidad de 98 camarones $\mathrm{m}^{-2}$. La melaza y el probiótico comercial estuvo compuesto por Bacillus spp. y Lactobacillus sp. El oxígeno, temperatura, salinidad, $\mathrm{pH}$, total de bacterias heterótrofas y parámetros zootécnicos (rendimiento, FCR, supervivencia y peso final) no mostraron diferencias significativas entre las estrategias de manejo. La concentración de nitrógeno amoniacal total (53-69\%) fue el principal compuesto de nitrógeno inorgánico que se acumuló. La melaza y los probióticos son estrategias de manejo importantes para incrementar el crecimiento del camarón en sistema intensivo sin recambio, sin embargo, la melaza es más económica que los probióticos. La adición de melaza basada en un porcentaje de alimentación diaria (en peso) con tasas de aplicación de $30 \%$ del peso del alimento por día y probiótico comercial, en viveros intensivos, sin liners y sin recambio de agua, no fue suficiente para el reciclado de todos los residuos de nitrógeno con $10 \mathrm{HP}_{\text {ha }}{ }^{-1}$.
\end{abstract}

Palabras clave: Melaza, probiótico, total de bacterias heterótrofas, parámetros

\begin{abstract}
A 16-week trial was carried out to evaluate an intensive culture system of Litopenaeus vannamei in commercial ponds with zero water exchange. Two management strategies were used: one with the addition of molasses (ML) and the second with commercial probiotic and molasses (PML), each with four replicates. Shrimp L. vannamei $(2.09 \pm 0.3 \mathrm{~g})$ were stocked in 2.6 ha ponds without liners at a density of 98 shrimp $\mathrm{m}^{-2}$. The commercial probiotics used with molasses was a mixture of Bacillus spp. and Lactobacillus sp. After 16 weeks, no significant differences were found in mean dissolved oxygen, temperature, salinity, pH, total heterotrophic bacteria and zootechnical parameters (yield, FCR, survival and final weight) between the two management strategies. Total ammonia nitrogen concentration (53 to 69\%) was the highest inorganic nitrogen compound. There were no significant differences between its concentrations in the two management strategies. The addition of molasses and probiotics are important management strategies for increased shrimp growth in an intensive system in ponds with zero water exchange, however, molasses is cheaper than the probiotics. Molasses inputs were based on a percentage of the daily feed allotments (by weight) and application rates of $30 \%$ of total daily feed in combination with commercial probiotics in intensive ponds without liners with zero water exchange was not sufficient to recycle all nitrogen waste with $10 \mathrm{HP} \mathrm{ha}^{-1}$.
\end{abstract}

Key words: Molasses, probiotics, total heterotrophic bacteria, zootechnical parameters

\section{INTRODUCTION}

From 1997 to 2003, shrimp production in Brazil expanded from 3,600 to more than 90,000 tons per year, and farm productivity increased from 1,050 to $6,084 \mathrm{~kg} \mathrm{ha}^{-1}$ year $^{-1}$, representing increases of more than $2,400 \%$ and $490 \%$, respectively (Simão et al. 2013). However, in recent year, there have been significant losses in Brazilian shrimp culture because of infectious myonecrosis virus (IMNV), white spot syndrome virus (WSSV) and bacterial diseases (Guerrelhas \& Teixeira 2012). As a result, production in 2011 was 69,571 tons with $3,510 \mathrm{~kg} \mathrm{ha}^{-1}$ year $^{-1}$ on 19,845 hectares (ABCC 2013). 
Brazilian shrimp farming is based on autotrophic systems with water exchange to maintain adequate water quality, which is wasteful of water resources and could become a source of environmental pollution through the discharge of feed waste and of nitrogen and phosphorus from the fertilizers (Hopkins et al. 1993). To practice modern, environmentally responsible shrimp farming, it is essential to reduce the volume of water exchanged, thus reducing pumping costs and the chance of introducing pathogens (Silva et al. 2009). This has other advantages including the use of feeds with lower protein levels (Azevedo et al. 2013), higher yield (Brito et al. 2014a), lower TAN wastes (Castillo-Soriano et al. 2013) and greater transformation of nitrogen into shrimp biomass (Brito et al. 2016). This is very important because in intensive culture systems, nitrogen wastes are a major problem due to their toxicity to cultured aquatic organisms, which affects the immune system and shrimp growth (Chen et al. 2012).

In recent years, intensive shrimp culture systems in tanks or raceway have used the addition of organic carbon to recycle nitrogen wastes (Avnimelech 2009). Various organic carbon sources like sugar (Gao et al. 2012), molasses (Maia et al. 2012), wheat bran (Megahed 2010), rice flour (Anand et al. 2013), tapioca flour (Asaduzzaman et al. 2010), acetate (Crab et al. 2010) and glycerol (Ekasari et al. 2010), can encourage the development of a heterotrophic microbial community in raceways or tanks. This contributes to the formation of aggregates that are useful to shrimp nutrition, increasing its survival and growth of Litopenaeus vannamei (Brito et al. 2014b).

Another important strategy used in shrimp culture is the addition of probiotics. The use of probiotics as farm animal feed supplements dates back to the 1970s and were originally incorporated to increase growth and improve health by enhancing disease resistance. The term probiotic in aquaculture generally refers to a bacterial supplement developed from a monoculture or mixed culture of selected bacteria (Farzanfar 2006). Research about probiotics have increased recently to identify their usefulness for enhancing infection resistance (Keysami et al. 2012), improved digestive enzyme activity (Nimrat et al. 2013), growth performance (Shen et al. 2010) and stimulating growth of plankton and bacterial communities (Maia et al. 2013).

These 2 strategies can help reduce the negative effects of increased stocking densities, thus decreasing FCR and improving water quality. This can improve the economics of shrimp culture, and increasing yields, because the microbial community plays an important role in recycling nutrients (Sánchez et al. 2012), and provides a source of nutrition, such as fatty acids DHA and EPA, which are essential to survival and shrimp growth (Van
Wyk 1999). In this context, this study evaluates an intensive culture system of L. vanname $i$ with the addition of molasses and probiotics in commercial ponds with zero water exchange.

\section{MATERIALS AND METHODS}

A trial was carried out in eight 2.6 ha ponds at the Aquarium Aquaculture Brazil Ltda., Mossoró, Rio Grande do Norte, Brazil ( $5^{\circ} 11^{\prime}$ 'S, 37 $20^{\prime}$ 'W), with zero water exchange. The experimental design had 2 management strategies: the addition of ML (molasses) and PML (a commercial probiotic with molasses) with 4 replicates each.

Twenty days prior to stocking, all eight ponds (with beds consisting of clayey and saline soil) were emptied. The intake and drainage gates were sealed and the ponds received two consecutive bacteria applications from screens of 500 and 1000 $\mu \mathrm{m}$. Wet areas were treated with chlorine (100 ppt). The treatment of the soil was performed by mechanical tilling and application of dolomitic limestone $\left(1,500 \mathrm{~kg} \mathrm{ha}^{-1}\right)$ (Maia et al. 2013).

After 5 days, the ponds were filled to a water level of $1.0 \mathrm{~m}$. The water was fertilized with urea and triple superphosphate (3.0 $\mathrm{mg} \mathrm{L}^{-1}$ of nitrogen and $0.3 \mathrm{mg} \mathrm{L}^{-1}$ of phosphorus). Three subsequent fertilizations ( 1.0 of nitrogen and $0.1 \mathrm{mg} \mathrm{L}^{-1}$ of phosphorus) were performed every 3 days prior to shrimp stocking. This procedure is a traditional management procedure for successive culture soon after harvesting. During the experiment, top fertilizations with urea (total $230 \mathrm{~kg} \mathrm{pond}^{-1}$ ) and triple super phosphate (total $23.5 \mathrm{~kg}_{\text {pond }}{ }^{-1}$ ) were performed, and the alkalinity of the water was corrected weekly with the application of dolomitic limestone (total of $8,062 \mathrm{~kg}$ pond $^{-1}$ ) (Maia et al. 2013).

A probiotic composed of Bacillus spp. and Lactobacillus sp. yeasts was administered to the ponds 7 days prior to stocking (probiotic treatment), using the following criteria: dilution in water at a proportion of $75.0 \mathrm{~g} \mathrm{~L}^{-1}$; placement of solution in two-liter plastic bottle; agitation and rest for 4 hours in the shade; further agitation and also sprinkling on ponds. Assuming a total aerobic count of $2.2 \times 10^{8}$ colony-forming units $\left(\mathrm{cfu} \mathrm{g}^{-1}\right)$ (specified as the minimal count by the manufacturer), the initial quantity administered to the ponds was $4.5 \mathrm{~kg}$. Supplementary applications $\left(162.5 \mathrm{~kg}\right.$ week ${ }^{-1}$ pond $\left.^{-1}\right)$ were performed over 16 consecutive weeks. (Maia et al. 2013).

Molasses was applied daily to each tank at the time of feeding as a source of carbohydrates to promote the growth of heterotrophic bacteria. Molasses inputs were based on a percentage of the daily feed allotments (by weight) with application rates of $30 \%$ of total daily feed. 
Postlarvae (PLs 12) of L. vannamei were obtained from a commercial laboratory and were raised in 2 raceways $(0.25$ ha, with liners and depths of $1.5 \mathrm{~m}$ ) until 30 days (average weight of $2.09 \mathrm{~g}$ ), at a stocking density of $700 \mathrm{PLs} \mathrm{m}^{-2}$ in salinity of $35 \mathrm{~g} \mathrm{~L}^{-1}$. The postlarvae were fed 3 times a day (at 0800 , 1200 and $1600 \mathrm{~h}$ ), with a commercial shrimp feed with $40 \%$ crude protein and $10 \%$ crude lipids, and adjusted daily according to the estimated shrimp consumption, mortality rate and leftover feed. The commercial ponds ( $2.6 \mathrm{ha}$ ) were stocked with shrimp $L$. vannamei $(2.09 \pm 0.3 \mathrm{~g}$ initial weight $)$ at a density of 98 shrimp $\mathrm{m}^{-2}$. The shrimp were fed 3 times a day (at 0800,1200 and $1600 \mathrm{~h}$ ), with a commercial shrimp feed (35\% crude protein and $7.5 \%$ crude lipids) in trays $\left(50 \mathrm{ha}^{-1}\right)$ and adjusted daily according to the estimated shrimp consumption, mortality rate and leftover feed.

Shrimp weight was monitored on a weekly basis to determine shrimp growth and adjust the amount of feed and molasses offered. At the end of the experiment, final weight, weekly growth, feed conversion ratio (FCR), survival and yield were determined based on the following equations: Final weight $(\mathrm{g})$ = final biomass ( $\mathrm{g}$ )/ survival; FCR = feed supplied (dry weight)/ biomass gain; Survival $(\%)=$ (number of individuals at the end of evaluation period / initial number of individuals stocked) $\mathrm{x}$ 100; Yield $\left(\mathrm{kg} \mathrm{ha}^{-1}\right)=$ final biomass $(\mathrm{kg}) /$ area of experimental unit (ha).

Dissolved oxygen and temperature were monitored (YSI model 55, Yellow Springs, Ohio, USA) twice a day (at 0800 and 1600 h). Salinity (YSI 30, Yellow Springs, Ohio, USA), pH (YSI model 100, Yellow Springs, Ohio, USA) was monitored twice a week (at $1600 \mathrm{~h}$ ). Total ammonia nitrogen (TAN), nitrite-nitrogen $\left(\mathrm{NO}_{2}-\mathrm{N}\right)$, nitrate-nitrogen $\left(\mathrm{NO}_{3}-\mathrm{N}\right)$, phosphate $\left(\mathrm{PO}_{4}{ }^{3}-\mathrm{P}\right)$ and alkalinity $\left(\mathrm{mg} \mathrm{L}^{-1} \mathrm{CaCO}_{3}\right)$ were monitored once a week (at $1600 \mathrm{~h}$ ), using a spectrophotometer (ALFAKIT-AT10P, Brazil) and a compact alkalinity kit (ALFAKIT, Brazil). Biochemical oxygen demand $\left(\mathrm{BOD}_{5}\right.$ ) was monitored once a week (at 1600h), following the described methods APHA (2005).

Water samples were analyzed for total heterotrophic bacteria (THB) on the $1^{\text {st }}, 5^{\text {th }}, 7^{\text {th }}, 10^{\text {th }}, 12^{\text {th }}, 14^{\text {th }}$ and $16^{\text {th }}$ weeks, by sampling the surface and bottom water. The water samples were collected in sterile glass bottles $(500 \mathrm{~mL})$ at a depth of $40 \mathrm{~cm}$ (surface water) and $0.4 \mathrm{~cm}$ above the sediment (bottom water) from 2 different locations (input and drainage) in each pond. All samples were placed in isothermal chests and immediately transported to the Environmental Microbiology and Fisheries Laboratory of the Ocean Sciences Institute of the Federal University at Ceará (Brazil). The preparation of the sample dilutions and bacteriological assays of the surface and bottom water, were sampled separately and their averages determined using the method described by APHA (2005). Bacteriological analysis of the water was conducted using appropriate sample dilutions $\left(10^{-1}\right.$ to $\left.10^{-5}\right)$ with sterilized saline solution $(2.5 \% \mathrm{NaCl})$. Standard count agar (TSA, Oxoid, UK) for THB were used. Each analysis was performed in duplicate by the spread plate method. To count the total heterotrophic bacteria (THB) the plates were incubated at $35^{\circ} \mathrm{C}$ for $48 \mathrm{~h}$ and colony forming units (cfu) were counted with a Quebec Darkfield Colony Counter (Leica Inc., Buffalo, New York) equipped with a guide plate ruled in square centimeters. Readings obtained with 25 and 250 colonies on a plate were used to calculate bacteria population numbers, recorded as cfu per sample unit.

The Student's t-test $(P<0.05)$ was used in the analysis of mean: final weight, survival, FCR, and yield. Water quality parameters and THB were analyzed by performing weekly measures after confirming homoscedasticity (Cochran, $P>$ 0.05 ) and normality (Shapiro-Wilk, $P>0.05$ ). Data on THB density and shrimp survival were analyzed using $\log (\mathrm{x})$ and arcsine-transformed data, respectively. Data analyses were performed using ASSISTAT Version 7.7 (Assistat Analytical Software, Campina Grande, Paraiba, Brazil).

\section{RESULTS}

Dissolved oxygen (2.82-9.14 $\left.\mathrm{mg} \mathrm{L}^{-1}\right)$, temperature $\left(26-28^{\circ} \mathrm{C}\right)$ and salinity (21- 22), $\mathrm{pH}(7.6-7.7)$ and $\mathrm{BOD}_{5}(17.6$ - $19.7 \mathrm{mg}$ $\left.\mathrm{L}^{-1}\right)$ showed no significant differences $(P>0.05)$ between the 2 management strategies (Table 1). The TAN concentration (53 to $69 \%$ ) was higher for dissolved inorganic nitrogen as compared to $\mathrm{NO}_{3}-\mathrm{N}$ (19 to $\left.35 \%\right)$ and $\mathrm{NO}_{2}-\mathrm{N}(11 \%)$. The concentration of inorganic nitrogen compounds showed no significant differences $(P>0.05)$ between management strategies (Table 1).

The mean water THB was significantly higher $(P<0.05)$ in ML than PML on the $10^{\text {th }}$ and $12^{\text {th }}$ weeks. However, there were no significant differences $(P>0.05)$ between management strategies (Table 1) for THB. The water THB varied from 3.76 to $5.54 \log _{10}$ cfu $\mathrm{mL}^{-1}$ in the ML treatment and from 3.16 to $4.85 \log _{10}$ cfu $\mathrm{mL}^{-1}$ in the PML treatment.

The weekly growth rate was from 0.22 to $1.01 \mathrm{~g} \mathrm{week}^{-1}$ in the molasses ponds (ML) and from 0.10 to $1.04 \mathrm{~g}$ week $^{-1}$ in the PML. There were no significant differences $(P>0.05)$ in yield, survival, final weight and FCR in the two management strategies (Table 2). 
Table 1. Water quality parameters of Litopenaeus vannamei in intensive commercial pond with zero exchange water / Parámetros de calidad de agua de Litopenaeus vannamei en viveros comerciales intensivos sin recambio de agua

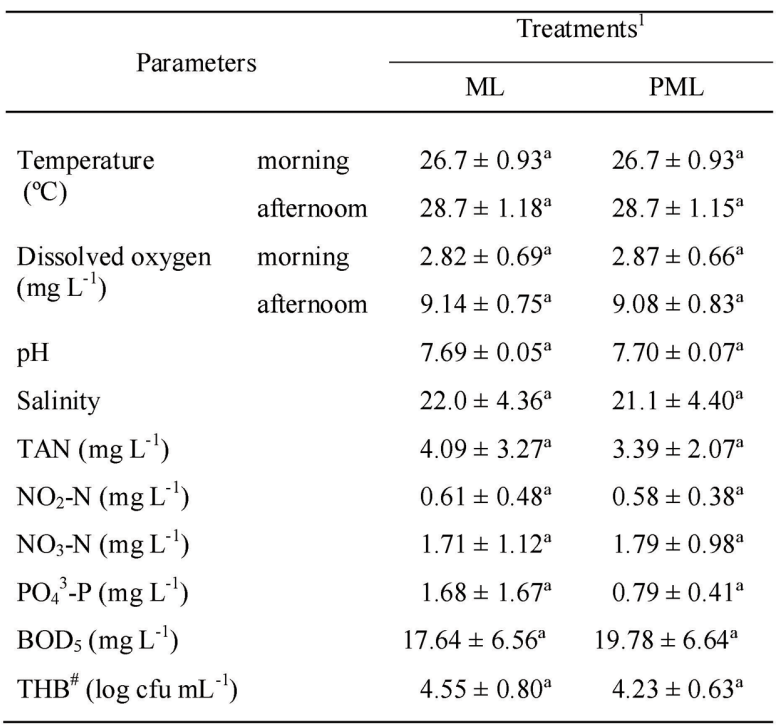

${ }^{1}$ The data correspond to the mean \pm standard deviation. Mean values in the same row with equal superscripts din't differ significantly from Student's t-test $(P<0.05)$. Total ammonia nitrogen (TAN), nitrite $\left(\mathrm{NO}_{2}-\mathrm{N}\right)$, nitrate $\left(\mathrm{NO}_{3}-\mathrm{N}\right)$, orthophosphate $\left(\mathrm{PO}_{4}{ }^{3}-\mathrm{P}\right), \mathrm{BOD}$ (biochemical oxygen demand) and THB (Total heterotrophic bacteria); "Data on THB density were analyzed using $\log \mathrm{x}$ transformed data

Table 2. Performance parameters of Litopenaeus vannamei in intensive commercial ponds with zero exchange water / Parámetros de crecimiento de Litopenaeus vannamei en viveros comerciales intensivos sin recambio de agua

\begin{tabular}{lcc}
\hline \multirow{2}{*}{ Parameters } & \multicolumn{2}{c}{ Treatments $^{1}$} \\
\cline { 2 - 3 } & ML & PML \\
\hline Survival (\%) & $84.88 \pm 4.54^{\mathrm{a}}$ & $75.05 \pm 9.91^{\mathrm{a}}$ \\
Final Weight $(\mathrm{g})$ & $11.28 \pm 0.75^{\mathrm{a}}$ & $10.69 \pm 0.33^{\mathrm{a}}$ \\
Yield $\left(\mathrm{kg} \mathrm{ha}^{-1}\right)$ & $8,875 \pm 614^{\mathrm{a}}$ & $8,228 \pm 911^{\mathrm{a}}$ \\
FCR & $1.51 \pm 0.11^{\mathrm{a}}$ & $1.53 \pm 0.09^{\mathrm{a}}$ \\
\hline
\end{tabular}

${ }^{1}$ The data correspond to the mean \pm standard deviation. Mean values in the same row with equal superscripts din't differ significantly from Student's t-test $(P<0.05)$. "Data on shrimp survival were analyzed using arcsine-transformed data

\section{Discussion}

The mean $\mathrm{NO}_{2}-\mathrm{N}$ and $\mathrm{NO}_{3}-\mathrm{N}$ temperature, salinity and $\mathrm{pH}$ concentrations of the culture water were within the range recommended for intensive shrimp culture by Van Wyk \& Scarpa (1999), however, the mean TAN was higher (Table 1). Anand et al. (2013) found higher TAN concentration in treatments with a lower $\mathrm{C} / \mathrm{N}$ ratio than a higher $\mathrm{C} / \mathrm{N}$ ratio, probably because there was less substrate for bacterial growth in the lower $\mathrm{C} / \mathrm{N}$. Brito et al. (2016) found higher concentrations of $\mathrm{NO}_{3}-\mathrm{N}$ in an intensive system with the addition of molasses as compared with $\mathrm{NO}_{2}-\mathrm{N}$ and TAN. However, Xu \& Pan (2013) found no significant effects between dietary protein level (25 and 35\%) and $\mathrm{C} / \mathrm{N}$ (15 and 20 ratio) for TAN, $\mathrm{NO}_{2}-\mathrm{N}$ and $\mathrm{NO}_{3}-\mathrm{N}$ concentrations during the time of the experiment.

The high TAN concentrations observed in this study are probably related to the low molasses application rates $(30 \%)$, anaerobiosis and depletions occurred at the pond bottoms, because of the use of only $10 \mathrm{Hp} \mathrm{ha}^{-1}(\sim 800 \mathrm{~kg}$ shrimp $\mathrm{HP}^{-1}$ ). Ebeling et al. (2006) suggest calculating carbohydrate inputs based on a percentage of the daily feed allotment (by weight) with application rates of $49 \%$ on days when using feed with $35 \%$ crude protein. Avnimelech (2009) recommended a proportion of $500 \mathrm{~kg}$ shrimp $\mathrm{HP}^{-1}$ in aeration in the heterotrophic system.

The addition of organic carbon (C:N ratio at 15-20:1) to the water in the raceways or tanks immobilizes inorganic nitrogen, transforming it into microbial protein. Anand et al. (2013) and Brito et al. (2014b) have shown, however, that the addition of probiotics lead to different results. Matias et al. (2002) did not find improved water quality in ponds with the addition of probiotics, while Wang et al. (2005) found improved water quality, probably due to differences in species, total aerobic count (colony-forming units) and the form of the probiotic administered.

According to Avnimelech (2009), aeration is an essential way to achieve higher yields in zero water exchange ponds with liners, because it circulates the water, provides oxygen and controls sludge, but the aerations should be well distributed throughout the ponds. Ponds without liners cannot use higher artificial aeration by paddle wheel, because this causes higher resuspension of bottom sediment and does not improve shrimp growth. Márquez et al. (2012) found a large increase in sludge and shrimp mortality, because of heavy fouling (by epicommensal bacteria, feces and uneaten feed) of the gills and difficulties in respiration. In this study, although artificial aeration was used, mean dissolved oxygen by morning was always below $3 \mathrm{mg} \mathrm{L}^{-1}$ (Table 1) in both treatments and anaerobiosis and depletions occurred in spots. This reduction coincided with greater $\mathrm{BOD}_{5}$ and may be related to an increase 
in the aerobic decomposition rate of organic matter. Anumber of mortalities were found in the $16^{\text {th }}$ week as a consequence of these interactions. Despite the small difference between treatments, peak and mean $\mathrm{BOD}_{5}$ values were similar, with ideal value established for aquaculture waters of $\leq 30.0 \mathrm{mg} \mathrm{L}^{-1}$ (Boyd 2000).

The increased levels of $\mathrm{PO}_{4}{ }^{3}-\mathrm{P}$ are expected in intensive shrimp ponds (Boyd 2000), especially those with zero or minimal exchange water. The accumulation of $\mathrm{PO}_{4}{ }^{3}-\mathrm{P}$ (which comes from the feed) suggests that it is not utilized by phytoplankton. This is probably due to the substitution of the microbiota from the phytoplankton community by bacteria. Thakur \& $\mathrm{Lin}$ (2003) found that a large portion of the $\mathrm{PO}_{4}{ }^{3}-\mathrm{P}$ ( 38.8 to $66.7 \%$ ) that enters ponds is deposited in the sediment. $\mathrm{PO}_{4}^{3}$-P concentrations in this study were much higher than those reported by Boyd (2000), which is adequate for aquaculture ponds $\left(0.3 \mathrm{mg} \mathrm{L}^{-1}\right)$.

The THB concentration was similar in the 2 management strategies (Table 1) in terms of both variation and mean concentrations, suggesting that the substrate availability in the water was similar in both. The addition of organic carbon was found to stimulate increased THB concentration in the water, according to Anand et al. (2013) and Kumar et al. (2014). Similar results were observed by Devaraja et al. (2002) with probiotic addition in shrimp ponds. This increase can improve water quality, because heterotrophic bacteria will immobilize inorganic nitrogen, which is the major waste nutrient in aquaculture, and convert this waste into microbial protein (Avnimelech 2009), which could be utilized as a source of supplemental feed for shrimp and have a positive effect on digestive enzyme activities (Xu \& Pan 2012).

The association between higher TAN and a decrease of dissolved oxygen certainly influenced shrimp growth, survival and yield. The survival rate observed in this study (Table 2) was higher than that found by Gao et al. (2012) and Maia et al. (2012), however, the final weight was similar (Table 2). The use of probiotics did not influence final weight as compared to molasses. Similar results were found by Rengpipat et al. (1998) using Bacillus in the feed for P. monodon for over 100 days of culture.

It is probable that anaerobiosis and depletions occurred at the pond bottom, reducing the influence of the probiotic. In addition, the commercial probiotic (total aerobic count of $2.2 \mathrm{x}$ $10^{8}$ colony-forming units $\mathrm{g}^{-1}$ ) does not seem to have the ideal concentration, because Shen et al. (2010) evaluated many doses and found better shrimp growth with total aerobic count of $5.0 \times 10^{8} \mathrm{cfu} \mathrm{g}^{-1}$ feed. Further studies are needed to evaluate different probiotic concentrations in an intensive system and to understand the role of Bacillus spp. and Lactobacillus sp. in zero exchange systems.

The FCR was lower than that found by Gao et al. (2012) with 150 shrimp $\mathrm{m}^{-2}$ (1.75-2.44) and higher than found by Maia et al. (2012) with 142-159 shrimp $\mathrm{m}^{-2}$ (1.24). Taw (2010) observed lower FCR (1.3 to 1.6) with $L$. vannamei in intensive ponds with liners and with zero or minimal exchange water. Rengpipat et al. (1998) and Horowitz \& Horowitz (2000) found similar FCR between treatments with probiotics and controls (without probiotics). The low growth rate influenced the time of culture in both treatments. The mean weekly growth $(0.57 \mathrm{~g})$ was lower than that found by Maia et al. (2012) (0.83 g) under the same shrimp farming system in commercial ponds (0.25 ha) with liners, paddle-wheel aerators $17 \mathrm{hp} \mathrm{ha}^{-1}$ and artificial substrate (28\% increased surface area).

The two strategies (with the addition of molasses and with and without probiotics) had higher yields than other Brazilian shrimp cultures $(<3,500 \mathrm{~kg}$ ha year-1 $)($ ABCC 2013). The results show $\left(\sim 8,000 \mathrm{~kg} \mathrm{ha} \mathrm{cycle}^{-1}\right)$ the viability of the addition of molasses and probiotics to intensive culture systems for $L$. vannamei in commercial ponds, with zero water exchange because it improved the environmental quality and provided a natural food source with a good nutritional composition for the shrimp.

In autotrophic systems in general, at daily feeding rates less than $300 \mathrm{~kg} \mathrm{ha}^{-1}\left(30 \mathrm{~g} \mathrm{~m}^{-2}\right)$, algal activity is the major factor in water quality. However, intensive systems can use higher feeding rates than semi-intensive systems, and nitrogen (feed wastes) can be incorporated into microbial protein, thus contributing to animal growth (Hargreaves 2013). Moreover, the heterotrophic system has bioactive compounds that contribute to improved immune response and shrimp performance. Xu \& Pan (2013) found the immune response of the $L$. vaname $i$ in a heterotrophic system was significantly higher than that of shrimp in clear water tanks operated with high water exchange. Jang et al. (2011) found that the expression of a prophenoloxidase-activating enzyme in hemocytes of $L$. vanname $i$ was enhanced significantly when shrimp were reared in a biofloc system. Becerra-Dorame et al. (2012) reported that $L$. vannamei reared in a heterotrophic system showed improved hemolymph parameters including superoxide dismutase activity.

In summary, the results of this experiment corroborate those of other studies in raceways and tanks with liners that reported the positive effect of the addition of molasses on production parameters in shrimp culture. Our results indicate that the addition of molasses in ponds without liners contributed to increased shrimp growth, because the heterotrophic bacteria used 
molasses with the substrate, and are a supplemental food source for shrimp in an intensive system. However, carbohydrate inputs based on a percentage of the daily feed allotments (by weight) with application rates of $30 \%$ for days when using feed with $35 \%$ crude protein and commercial probiotics in intensive ponds with zero water exchange without liners is not sufficient for recycling all nitrogen waste with $10 \mathrm{HP} \mathrm{ha}^{-1}$. Moreover, anaerobiosis and oxygen depletions do not seem to be environmentally suitable to Bacillus spp. and Lactobacillus sp. growth and the total aerobic count of $2.2 \times 10^{8}$ colonyforming units $\mathrm{g}^{-1}$ does not seem to be an adequate concentration for an intensive system. In a zero- or minimal water exchange system it is necessary to improve the artificial aeration systems and water circulation to decrease anaerobiosis in the ponds.

\section{LITERATURE CITED}

ABCC. 2013. Levantamento da infraestrutura produtiva e dos aspectos tecnológicos, econômicos, sociais e ambientais da carcinicultura marinha no Brasil em 2011, 82 pp. Associação Brasileira de Criadores de Camarão, Natal.

Anand PSS, S Kumar, A Panigrahi, TK Ghoshal, JS Dayal, G Biswas, JK Sundaray, D De, RR Ananda, AD Deo, SM Pillai \& P Ravichandran. 2013. Effects of C:N ratio and substrate integration on periphyton biomass, microbial dynamics and growth of Penaeus monodon juveniles. Aquaculture International 21:511-524.

APHA. 2005. Standard methods for the examination of water and wastewater, pages? American Public Health Association, Washington.

Asaduzzaman M, SMS Rahman, ME Azim, MA Islam, MA Wahab MCJ Verdegem \& JAJ Verreth. 2010. Effects of $\mathrm{C} / \mathrm{N}$ ratio and substrate addition on natural food communities in freshwater prawn monoculture ponds. Aquaculture 306(1-4): 127-136.

Avnimelech Y. 2009. Biofloc technology. A practical guide book, 182 pp. The World Aquaculture Society, Baton Rouge.

Azevedo CMSB, RBS Sales, AMV Arruda, BR Simão \& LO Brito. 2013. Desempenho do camarão Litopenaeus vannamei $\mathrm{em}$ sistema sem renovação de água com diferentes níveis de proteína bruta e adição de melaço. Arquivos de Ciências do Mar 46(2): 40-46.

Becerra-Dorame JM, LR Martinez-Cordova, M MartínezPorchas, J Hernández-López, JA López-Elías \& F Mendoza-Cano. 2012. Effect of using autotrophic and heterotrophic microbial-based-systems for the pre-grown of Litopenaeus vannamei, on the production performance and selected haemolymph parameters. Aquaculture Research 45(5): 944-948.

Boyd CE. 2000. Farm effluent during draining for harvest. Global Aquaculture Advocate 3: 26-27.

Brito LO, R Arantes, C Magnotti, R Derner, F Pchara, A Olivera \& L Vinatea. 2014a. Water quality and growth of Pacific white shrimp Litopenaeus vannamei (Boone) in coculture with green seaweed Ulva lactuca (Linaeus) in intensive system. Aquaculture International 22(2): 497-508.
Brito LO, LAV Arana, RB Soares, W Severi, RH Miranda, SMBC Silva, MRM Coimbra \& AO Galvez. 2014b. Water quality, phytoplankton composition and growth of Litopenaeus vannamei (Boone) in an integrated biofloc system with Gracilaria birdiae (Greville) and Gracilaria domingensis (Kutzing). Aquaculture International 22: 16491664.

Brito LO, AM Chagas, EP Silva, RB Soares, W Severi \& AO Galvez. 2016. Water quality, Vibrio density and growth of Pacific white shrimp Litopenaeus vannamei (Boone) in an integrated biofloc system with red seaweed Gracilaria birdiae (Greville). Aquaculture Research 47: 940-950.

Castillo-Soriano FA, V Ibarra-Junquera, P EscalanteMinakata, O Mendoza-Cano, JJ Ornelas-Paz, JC Almanza-Ramírez \& AO Meyer-Willerer. 2013. Nitrogen dynamics model in zero water exchange, low salinity intensive ponds of white shrimp, Litopenaeus vannamei, at Colima, México. Latin American Journal of Aquatic Research 41: 68-79.

Chen YY, SS Sim, SL Chiew, ST Yeh, CH Liou \& JC Chen. 2012. Dietary administration of a Gracilaria tenuistipitata extract produces protective immunity of white shrimp Litopenaeus vannamei in response to ammonia stress. Aquaculture 370-371: 26-31.

Crab R, B Chielens, M Wille, P Bossier \& W Verstraete. 2010. The effect of different carbon sources on the nutritional value of bioflocs, a feed for Macrobrachium rosenbergii postlarvae. Aquaculture Research 41(40): 559567.

Devaraja TN, F Yusoff \& M Shariff. 2002. Changes in bacterial populations and shrimp production in ponds treated with commercial microbial products. Aquaculture 206(3-4): 254-256.

Ebeling JM, MB Timmons \& JJ Bisogni. 2006. Engineering analysis of the stoichiometry of photoautotrophic, autotrophic, and heterotrophic removal of ammonia-nitrogen in aquaculture systems. Aquaculture 257(1-4): 346-358.

Ekasari J, R Crab \& W Verstraete. 2010. Primary nutritional content of bioflocs cultures with different organic carbon sources and salinity. Hayati Journal Bioscience 17(3): 125130.

Farzanfar A. 2006. The use of probiotics in shrimp aquaculture. FEMS Immunology and Medical Microbiology 48: 149-158.

Gao L, HW Shan, TW Zhang, WY Bao \& S Ma. 2012. Effects of carbohydrate addition on Litopenaeus vannamei intensive culture in a zero-water exchange systems. Aquaculture 342343: 89-96.

Guerrelhas ACB \& AP Teixeira. 2012. Panorama da situação da mancha branca no Nordeste. Panorama da Aquicultura 22(129): 38-41.

Hargreaves JA. 2013. Biofloc Production Systems for Aquaculture. Southern Regional Aquaculture Center-SRAC Publication 4503.

Hopkins JE, R Hamilton, P Sandifer, C Browdy \& A Stokes. 1993. Effect of water exchange rate on production, water quality, effluent characteristics and nitrogen budgets of intensive shrimp ponds. Journal of the World Aquaculture Society 24(3): 304-320. 
HorowitzA \& S Horowitz. 2000. Sludge - An obstacle to shrimp health. Global Aquaculture Advocate 2(6): 27-28.

Jang IK, Z Pang, J Yu, SK Kim, HC Seo \& YR Cho. 2011. Selectively enhanced expression of prophenoloxidase activating enzyme 1 (PPAE1) at a bacteria clearance site in the white shrimp. Litopenaeus vannamei. BMC Immunology 12,70 .

Keysami MA, M Mohammadpour \& CR Saad. 2012. Probiotic activity of Bacillus subtilis in juvenile freshwater prawn, Macrobrachium rosenbergii (de Man) at different methods of administration to the feed. Aquaculture International 20: 499-511.

Kumar S, PSS Anand, D De, JK Sundaray, RR Ananda, G Biswas, AG Ponniah, TK Ghoshal, AD Deo, A Panigrahi \& M Muralidhar. 2014. Effects of carbohydrate supplementation on water quality, microbial dynamics and growth performance of giant tiger prawn (Penaeus monodon). Aquaculture International 22: 901-912.

Maia EP, GA Modesto, LO Brito \& AO Galvez. 2012. Crescimento, sobrevivência e produção de Litopenaeus vannamei cultivado em sistema intensivo. Pesquisa Agropecuária Pernambucana 17(1): 15-19.

Maia EP, GA Modesto, LO Brito \& A Oliveira \& TCV Gesteira. 2013. Effect of a commercial probiotic on bacterial and phytoplankton concentration in intensive shrimp farming (Litopenaeus vannamei) recirculation systems. Latin American Journal of Aquatic Research 41: 126-13779.

Márquez JEQ, ER Andreatta, L Vinatea, A Olivera \& LO Brito. 2012. Efeito da densidade nos índices zootécnicos da criação de camarões Litopenaeus schmitti. Boletim do Instituto de Pesca 38(2): 145-153.

Matias HB, FM Yusoff, M Shariff \& O Azhar. 2002. Effects of commercial microbial products on water quality in tropical shrimp culture ponds. Asian Fisheries Science 15: 239-248.

Megahed ME. 2010. The effect of microbial biofloc on water quality, survival and growth of the green tiger (Penaeus semisulcatus) fed with different crude protein levels. Journal of the Arabian Aquaculture Society 5(2): 119-142.

Nimrat S, P Tanutpongpalin, K Sritunyalucksana, T Boonthai \& V Vuthiphandchai. 2013. Enhancement of growth performance, digestive enzyme activities and disease resistance in black tiger shrimp (Penaeus monodon) postlarvae by potential probiotics. Aquaculture International 21: 655-666.

Rengpipat S, W Phianphak, S Piyatiratitivorakul \& P Menasveta. 1998. Effects of a probiotic bacterium on black tiger shrimp Penaeus monodon survival and growth. Aquaculture 167(3-4): 301-313.
Sánchez DR, JM Fox, D Gatlin \& AL Lawrence. 2012. Dietary effect of squid and fish meals on growth and survival of Pacific white shrimp Litopenaeus vannamei in the presence or absence of phytoplankton in an indoor tank system. Aquaculture Research 43: 1880-1890.

Shen WY, LL Fu, WF Li \& YR Zhu. 2010. Effect of dietary supplementation with Bacillus subtilis on the growth, performance, immune response and antioxidant activities of the shrimp (Litopenaeus vannamei). Aquaculture Research 41: 1691-1698.

Silva UL, FP Melo, RB Soares, DBN Spanghero \& ES Correia. 2009. Efeito da adição do melaço na relação carbono/nitrogênio no cultivo de camarão Litopenaeus vannamei na fase berçário. Acta Scientiarum. Biological Sciences 31(4): 337-343.

Simão BR, LO Brito, ASC Maia, LC Miranda \& CMSB Azevedo. 2013. Comparing stocking densities and feeding strategies in a shrimp and tilapia polyculture in tanks. Pesquisa Agropecuária Brasileira 48(8): 1088-1095.

Taw N. 2010. Biofloc technology expanding at white shrimp ponds farms. Global Aquaculture Advocate 13(3): 20-22.

Thakur DP \& CK Lin. 2003. Water quality and nutrient budget in closed shrimp (Penaeus monodon) culture systems. Aquaculture Engineering 27: 159-176.

Van Wyk P. 1999. Nutrition and feeding of Litopenaeus vannamei in intensive culture systems. In: Van Wyk P, M Davis-Hodgkins, R LaramoreR, KL Main, J Mountain \& J Scarpa (eds). Farming marine shrimp in recirculating freshwater systems, 125-140 pp. Florida Department of Agriculture and Consumer Services - Harbor Branch Oceanic Institute, Florida.

Van Wyk P \& J Scarpa. 1999. Water quality requirements and management. In: Van Wyk P, M Davis-Hodgkins, R Laramore, KL Main, J Mountain \& J Scarpa (eds). Farming marine shrimp in recirculating freshwater systems, pp. 141162. Florida Department of Agriculture and Consumer Services - Harbor Branch Oceanic Institute, Florida.

Xu WJ \& LQ Pan. 2013. Enhancement of immune response and antioxidant status of Litopenaeus vannamei juvenile in biofloc-based culture tanks manipulating high $\mathrm{C} / \mathrm{N}$ ratio of feed input. Aquaculture 412-413: 117-124.

Xu WJ \& LQ Pan. 2012. Effects of bioflocs on growth performance, digestive enzyme activity and body composition of juvenile Litopenaeus vannamei in zero-water exchange tanks manipulating $\mathrm{C} / \mathrm{N}$ ratio in feed. Aquaculture 356/357: 147-152.

Wang YB, ZR Xu \& MS Xia. 2005. The effectiveness of commercial probiotics in northern white shrimp Penaeus vannamei ponds. Fisheries Science 71: 1036-1041. 